\title{
Assesment of normal tissue radiosensitivity in cervical tumors
}

\author{
Ana TS Carvalho ${ }^{1,2^{*}}$, Hellen S Cintra ${ }^{1,2}$, Nathany R Barbosa ${ }^{1,3}$, Juliana CD Pinezi ${ }^{1,4}$, Renata BA Soares ${ }^{1,2,3}$ \\ From São Paulo Advanced School of Comparative Oncology \\ Águas de São Pedro, Brazil. 30 September - 6 October 2012
}

\section{Background}

In Brazil, cervical cancer is the second most common malignant tumor among women. Radiation therapy is part of its interdisciplinary management. The major challenge of modern medicine in radiotherapy is to develop predictive methods that can determine the level of radiosensitivity of the patient and the healthy surrounding tissue in order to individualize the prescribed radiation dose, and to prevent severe side effects, promoting better local tumor control. This study evaluated the acute and chronic adverse effects on the skin, lower gastrointestinal tract and urinary tract of radiotherapy in 47 patients with cervical cancer.

\section{Materials and methods}

After signing the informed consent agreement, a sample of peripheral blood of 47 patients was collected then the DNA was extracted. TP53 and ATM sequences were amplified to be sequenced.

\section{Results}

Univariate analysis showed that age was strongly associated with a risk of acute skin toxicity $(p=0,023)$. Patients who received a high dose of external beam radiation and patients who have undergone brachytherapy, showed a significantly higher incidence of chronic urinary tract toxicity $(p=0,031)$ and $(p=0,019)$, respectively. The exchange $\mathrm{G}>\mathrm{A}$ in the position 5557 of the ATM gene was significantly associated with the risk of acute lower gastrointestinal tract toxicity $(p=0,008)$.

\section{Conclusions}

Our data corroborate the importance of investigating genetic profiles in order to predict adverse side effects in

\footnotetext{
* Correspondence: hanaterra@gmail.com

'Laboratory of Oncogenetics and Radiobiology, Goiânia, GO, Brazil

Full list of author information is available at the end of the article
}

patients with cervical cancer undergoing radiotherapy. TP53 and ATM, known to play an important role in DNA repair pathways, are probably capable of modifying responses of normal tissues to radiotherapy.

\section{Financial support}

FINEP (Rede GENOPROT) and CNEN.

\section{Author details}

${ }^{1}$ Laboratory of Oncogenetics and Radiobiology, Goiânia, GO, Brazil. ${ }^{2}$ Genetics Master's Program, PROPE, PUC, Goiânia, GO, Brazil. Department of Medicine, PUC, Goiânia, GO, Brazil. ${ }^{4}$ Medicine Faculty, Radiology Department, USP, São Paulo, SP, Brazil.

Published: 4 April 2013

\section{doi:10.1186/1753-6561-7-S2-P6}

Cite this article as: Carvalho et al:: Assesment of normal tissue radiosensitivity in cervical tumors. BMC Proceedings 2013 7(Suppl 2):P6.
Submit your next manuscript to BioMed Central and take full advantage of:

- Convenient online submission

- Thorough peer review

- No space constraints or color figure charges

- Immediate publication on acceptance

- Inclusion in PubMed, CAS, Scopus and Google Scholar

- Research which is freely available for redistribution
() Biomed Central

\section{() Biomed Central}

